Article

\title{
Synthesis and Characterization of the Ethylene-Carbonate-Linked L-Valine Derivatives of 4,4-Dimethylcurcumin with Potential Anticancer Activities
}

\author{
Der-Yen Lee ${ }^{1}$, Hui-Yi Lin ${ }^{2}$, Manickavasakam Ramasamy ${ }^{3}$, Sheng-Chu Kuo ${ }^{2,3,4}$, Pei-Chih Lee ${ }^{5,6, *(1)}$ \\ and Min-Tsang Hsieh $2,3,4, *$ (D) \\ 1 Graduate Institute of Integrated Medicine, China Medical University, No. 91, Hsueh-Shih Road, \\ Taichung 40402, Taiwan; deryen.lee@mail.cmu.edu.tw \\ 2 Research Center for Chinese Herbal Medicine, China Medical University, Taichung 40402, Taiwan; \\ pingababy@yahoo.com.tw (H.-Y.L.); sckuo@mail.cmu.edu.tw (S.-C.K.) \\ 3 School of Pharmacy, China Medical University, Taichung 40402, Taiwan; u106055122@cmu.edu.tw \\ 4 Chinese Medicinal Research and Development Center, China Medical University Hospital, \\ Taichung 40447, Taiwan \\ 5 Graduate Institute of Biomedical Sciences, China Medical University, Taichung 40402, Taiwan \\ 6 Research Center for Cancer Biology, China Medical University, Taichung 40402, Taiwan \\ * Correspondence: pclee@mail.cmu.edu.tw (P.-C.L.); t21917@mail.cmu.edu.tw (M.-T.H.)
}

check for

updates

Citation: Lee, D.-Y.; Lin, H.-Y.;

Ramasamy, M.; Kuo, S.-C.; Lee, P.-C.;

Hsieh, M.-T. Synthesis and

Characterization of the

Ethylene-Carbonate-Linked L-Valine Derivatives of 4,4-Dimethylcurcumin with Potential Anticancer Activities. Molecules 2021, 26, 7050. https:// doi.org/10.3390/molecules26227050

Academic Editor: Helen Osborn

Received: 6 November 2021

Accepted: 20 November 2021

Published: 22 November 2021

Publisher's Note: MDPI stays neutral with regard to jurisdictional claims in published maps and institutional affiliations.

Copyright: (c) 2021 by the authors. Licensee MDPI, Basel, Switzerland. This article is an open access article distributed under the terms and conditions of the Creative Commons Attribution (CC BY) license (https:// creativecommons.org/licenses/by/ $4.0 /)$.

\begin{abstract}
Natural phenolic products from herbal medicines and dietary plants constitute the main source of lead compounds for the development of the new drug. 4,4-Dimethylcurcumin (DMCU) is a synthetic curcumin derivative and exhibits anticancer activities against breast, colon, lung, and liver cancers. However, further development of DMCU is limited by unfavorable compound properties such as very low aqueous solubility and moderate stability. To increase its solubility, we installed either or both of the ethylene-carbonate-linked L-valine side chains to DMCU phenolic groups and produced targeted 1-trifluoroacetic acid (1-TFA) and 2-trifluoroacetic acid (2-TFA) derivatives. The terminus L-valine of ethylene-carbonate-linked side chain is known to be a L-type amino acid transporter 1 (LAT1) recognition element and therefore, these two derivatives were expected to readily enter into LAT1-expressing cancer cells. In practice, 1-TFA or 2-TFA were synthesized from DMCU in four steps with 34-48\% overall yield. Based on the corresponding LC-MS analysis, water solubility of DMCU, 1-TFA, and 2-TFA at room temperature $\left(25 \pm 1^{\circ} \mathrm{C}\right)$ were $0.018,249.7$, and $375.8 \mathrm{mg} / \mathrm{mL}$, respectively, indicating $>10,000$-fold higher solubility of 1-TFA and 2-TFA than DMCU. Importantly, anti-proliferative assay demonstrated that 2-TFA is a potent anti-cancer agent against LAT1-expressing lung cancer cells NCI-H460, NCI-H358, and A549 cells due to its high intracellular uptake compared to DMCU and 1-TFA. In this study, we logically designed and synthesized the targeted compounds, established the LC-MS analytical methods for evaluations of drug solubility and intracellular uptake levels, and showed improved solubility and anti-cancer activities of 2-TFA. Our results provide a strategical direction for the future development of curcuminoid-like phenolic compounds.
\end{abstract}

Keywords: cellular uptake; 4,4-dimethylcurcumin; LC-MS spectroscopy; lung cancer; water solubility

\section{Introduction}

Plant-derived phenolic compounds such as stilbenoids, lignans, flavonoids and curcuminoids constitute major sources of natural therapeutic agents and have been shown to have wide applications in chemoprevention and degenerative diseases [1-3]. These natural products endowed with metabolically unstable functional groups often exhibit moderateto-high in vitro potency but unobvious in vivo efficacy [4]. The discrepancies between the in vitro and in vivo effects mainly stem from phenolic functionalities which are highly 
prone to form phenol glucuronide and sulfate conjugates by the phase II metabolic enzymes [5]. Therefore, structural modifications on the phenol group are potential strategies for further drug development. 4,4-Dimethylcurcumin (DMCU) is a synthetic derivative of curcumin via the di-methylation at the 4-position of linear 3,5-dione-containing chain of curcumin [6].

The previous structure-activity relationship (SAR) analysis on curcuminoid derivatives showed that disconnection of the highly conjugated enol system exerted positive effects on the stability and pharmaceutical activities [7]. Hence, DMCU exhibited improved anticancer activity against the MCF-7 breast cancer, HCT-116 colon cancer, A549 lung cancer and HepG2 liver cancer cell lines than curcumin [8], conceivably due to the greater reactive oxygen species producing activity and free radical scavenging activity compared to curcumin [9].

The overexpression of esterase, which functions with ester groups, is generally observed in several cancer cells [10]. Recently, we discovered a series of unique bis(hydroxymethyl) alkanoate derivatives of curcuminoids as efficacious anticancer agents [11]. These curcuminoid derivatives could induce $\mathrm{G}_{2} / \mathrm{M}$ phase arrest, autophagy, mitochondrial-associated apoptosis and ER-stress-induced apoptosis in human breast adenocarcinoma MDA-MB231 cells [12]. Among these synthetic analogs, 4,4-dimethyl substituted curcuminoid 2,2-bis(hydroxymethyl)propionate (DMCU-HMP), can be structurally regarded as an ester derivative of DMCU and showed potential anti-cancer activities against MDA-MB-231 breast cancer and HCT-116 colon cancer cell with the $\mathrm{IC}_{50}$ values of 2.2 and $3.1 \mu \mathrm{M}$, respectively. DMCU-HMP is expected to convert into DMCU in vivo because the 2,2bis(hydroxymethyl) propionate group of DMCU-HMP could readily cleave upon treatment with a considerable amount of esterase that usually exists in plasma, gastrointestinal tract, and liver, respectively. Shortly thereafter, our pharmacokinetic evaluations of DMCU-HMP illustrated that DMCU appeared in serum of mice after oral administration of DMCU-HMP and both DMCU-HMP and DMCU are contributors to in vivo antitumor efficacy [13]. A formulation study of DMCU-HMP is still ongoing in our lab with the intention of increasing oral bioavailability. In light of these promising anticancer effects and predictable high intrinsic clearance of DMPU, we attempted to develop alternative drug substances of DMCU-HMP by the modification of DMCU as anticancer agents against lung cancer. L-type amino acid transporter 1 (LAT1, also known as SLC7A5) belongs to a member of the solute carrier (SLC) family that can mediate the transportation of endogenous and exogenous bio-substances including amino acids, sugar molecules, biologically essential metal cations, fatty acids, neurotransmitters and pharmaceutical drugs across the cell membranes $[14,15]$. LAT1 functions as a sodium-/pH-independent transporter and preferably import branched-chain amino acids (BCAAs) such as L-leucine, L-isoleucine, L-valine, L-tyrosine and L-tryptophan into cells $[16,17]$.

Recent studies demonstrated that the LAT1 expression in lung cancer cells was significantly higher than in normal cells [18]. The overexpression of LAT1 cause enhanced nutrient absorption that is essential to rapid tumor growth in lung cancers. Inhibition of LAT1 retarded the amino acid uptake and mTOR phosphorylation, suggesting that LAT1 may act as a diagnostic biomarker or therapeutic drug target $[19,20]$. Recent studies indicated that treatment of anticancer drug molecules linked with the branched-chain amino acid promoiety as LAT1 recognition elements such as L-valine [21], L-tryptophan [22], and L-leucine [23], caused higher LAT1-mediated drug cellular uptake and greater anticancer activity than their parent compounds. The low solubility and poor metabolic stability of DMCU are still unfavorable to drug discovery. It was then anticipated that incorporating BCAAs into DMCU can have beneficial impacts on the drug solubility and intracellular uptake, leading to potent antiproliferative activity in LAT1-expressing cancer cell.

Here, we developed the targeted derivatives by installing either or both of the ethylenecarbonate-linked L-valine side chains to DMCU and characterized their solubility, stability, and antiproliferative activity LAT1-expressing lung tumor cells. 


\section{Results and Discussion}

\subsection{Synthesis}

DMCU with a direct linkage of BCAA to sterically congested phenol group may restrict the close proximity of LAT1 and lower down the enzyme recognition. We anticipated that the introduction of a self-immolating linker between the phenol group and BCAA can tackle the above problem [24]. In the regard, the target derivative 1 was prepared through the addition of a two-carbon side chain to the DMCU phenol group via the connection of a carbonate functionality (Figure 1 ). The $N$-terminus of the two-carbon side chain was linked to a BCAA by an amide bonding. We selected L-valine as the BCAA source since the previous metabolomic analysis indicated that L-valine was increased in the tumors of NSCLS patients, implying NSCLCs prefer to acquire L-valine [25]. To improve LAT recognition, compound $\mathbf{2}$ was designed as a di-substituted derivative incorporating the ethylene-carbonate-linked L-valine chains on both of the $D M C U$ phenol groups.
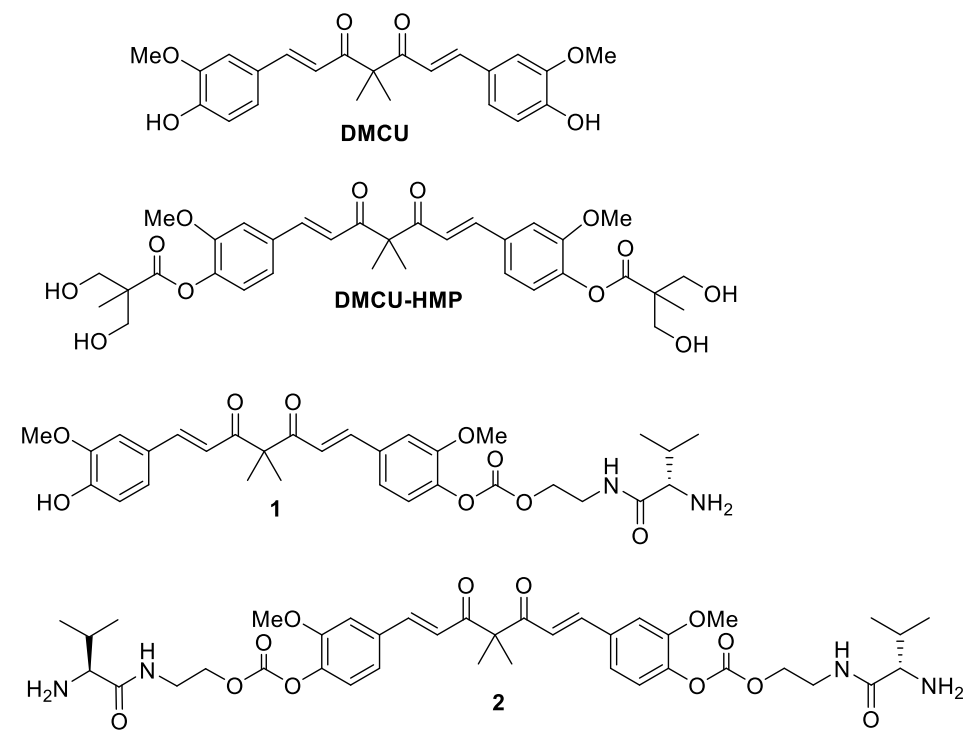

Figure 1. Structure of DMCU, DMCU-HMP, 1 and 2.

The procedures employed for the synthesis of targeted compounds $\mathbf{1}$ and $\mathbf{2}$ are depicted in Scheme 1. The required DMCU was prepared according to a three-step sequence reported in the literature [26]. Initially, the commercially available Boc-L-valine 3 was reacted with 2-aminoethanol 4 in the presence of HOTT and $\mathrm{Et}_{3} \mathrm{~N}$ to provide the amide product 5 in $82 \%$ yield. Under treatment with 4-nitrophenyl chloroformate and DIPEA, 5 was converted into 6 in $87 \%$ yield. One equivalent or excess amount of 6 was coupled with the deprotonated DMCU, formed in situ by the treatment of $\mathbf{D M C U}$ with $\mathrm{Cs}_{2} \mathrm{CO}_{3}$, to afford compound $\mathbf{7}$ and $\mathbf{8}$, respectively. Compound $\mathbf{7}$ and $\mathbf{8}$ thus obtained were subjected to Boc deprotection under the standard conditions to give $\mathbf{1}$ and $\mathbf{2}$, respectively. The preliminary stability test was performed with NMR by applying 2 as a typical example. As shown in Figure 2A, 2 gradually degraded into unidentified products under room temperature as the storage time increased. Based on our previous experience in the synthesis of DMCU-HMP, the instability could be ascribed to the cross-hydrolysis of carbonate group by the terminal amino group of side chain. Salt formation reactions of the $N$-terminal L-valine were then carried out to cap the nucleophilic amino group. Between the resulting trifluoroacetic acid (TFA) salt and $\mathrm{HCl}$ salt of compound 2, the stability of TFA salt (2-TFA) was greatly improved compared to its free form. The HPLC analysis (Figure 2B) indicated that solid 2-TFA can be stored in a closed vial under room temperature for 6 days without loss in purity. 2-TFA is also stable in DMSO solution ( $0.1 \mathrm{M}$ concentration). After 6-day storage at room temperate, the purity of 2-TFA remained intact. Accordingly, a similar salt formation procedure was employed to produce the stable 1-TFA. Compound 1-TFA along with 2-TFA were then applied for the following evaluations. 


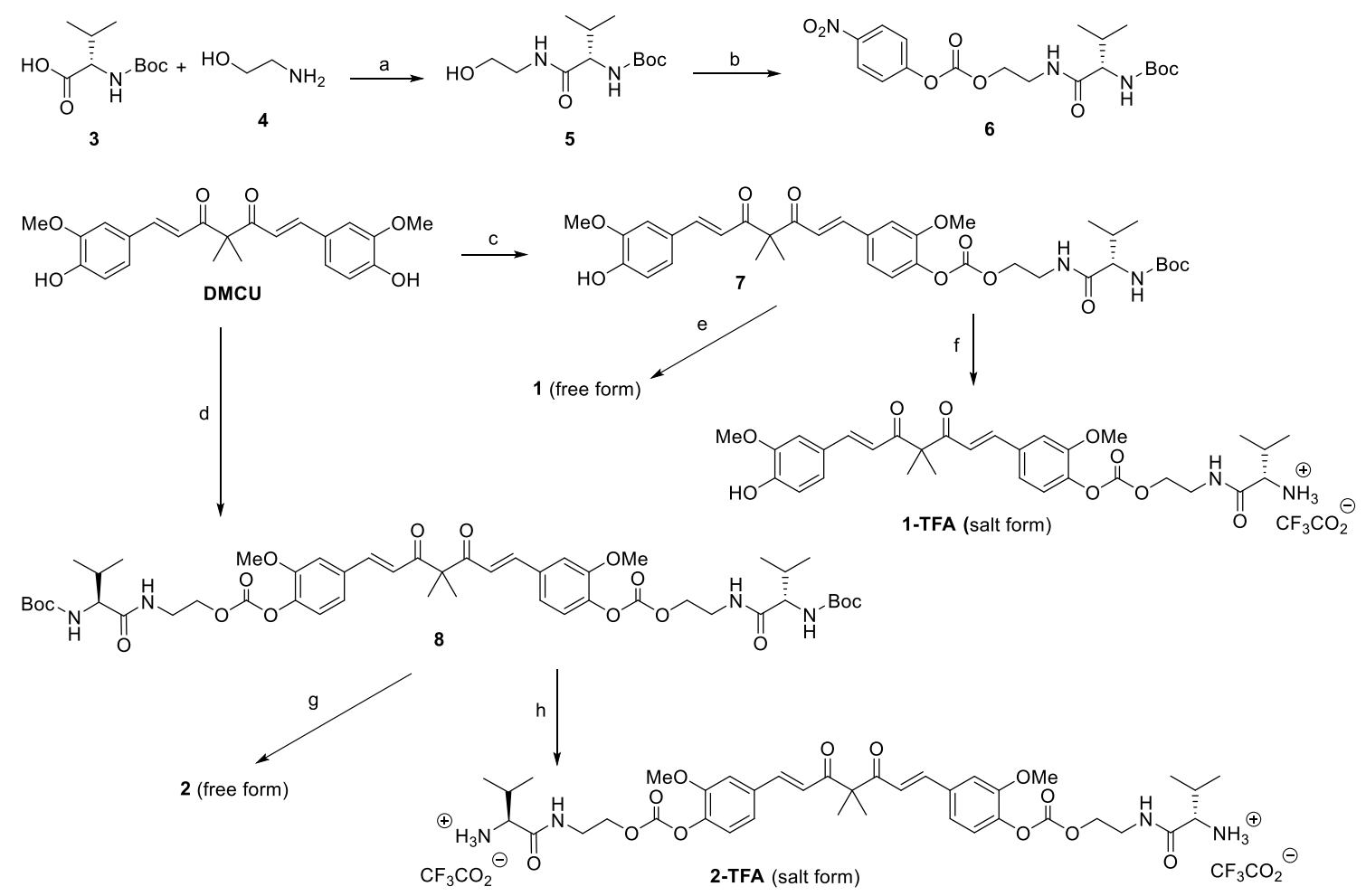

Scheme 1. Reagents and conditions: (a) HOTT, $\mathrm{Et}_{3} \mathrm{~N}, \mathrm{CH}_{3} \mathrm{CN}, \mathrm{rt}, 3.5 \mathrm{~h}, 82 \%$; (b) 4-nitrophenyl chloroformate, DIPEA, $\mathrm{CH}_{2} \mathrm{Cl}_{2}, \mathrm{rt}, 4 \mathrm{~h}, 87 \%$; (c) 6 (0.9 equiv), $\mathrm{Cs}_{2} \mathrm{CO}_{3}, \mathrm{DMF}, \mathrm{rt}, 3.5 \mathrm{~h}, 48 \%$; (d) 6 (2.7 equiv), $\mathrm{Cs}_{2} \mathrm{CO}_{3}, \mathrm{DMF}, \mathrm{rt}, 6 \mathrm{~h}, 68 \%$; (e) $\mathrm{HCl}$, $\mathrm{CH}_{2} \mathrm{Cl}_{2}, \mathrm{rt}, 3.5 \mathrm{~h}$ then $\mathrm{Et}_{3} \mathrm{~N}$; (f) TFA, $\mathrm{CH}_{2} \mathrm{Cl}_{2}, 4 \mathrm{~h}, \mathrm{rt},>95 \%$ (g) $\mathrm{HCl}, \mathrm{CH}_{2} \mathrm{Cl}_{2}, \mathrm{rt}, 3.5 \mathrm{~h}$ then Et $3 \mathrm{~N}$; (h) TFA, CH $\mathrm{Cl}_{2}, 4 \mathrm{~h}, \mathrm{rt}$, $>95 \%$.

\subsection{Water Solubility Analysis of DMCU, 1-TFA, and 2-TFA}

As described above, DMCU showed an unfavorable drug-like property due to its poor solubility. DMCU is virtually insoluble in water and only partially dissolved in some hydrophilic solvents, such as methanol and DMSO. 1-TFA, and 2-TFA with the linkage of L-valine-TFA side chain on either or both of the phenol groups were expected to show an increment of water solubility. We used LC-MS analysis to determine the water solubility of DMCU, 1-TFA, and 2-TFA. Initially, the LC signals detected by ESI+ mode for each compound were assigned as follows: $[\mathrm{M}+\mathrm{Na}]^{+}$for DMCU, $[\mathrm{M}+\mathrm{H}]^{+}$for 1-TFA, and $[\mathrm{M}+2 \mathrm{H}]^{2+}$ for 2-TFA (Figure 3A). The extracted ion chromatogram (XIC) was acquired by extracting the $m / z$ signal of 419.1461 for DMCU, 583.2652 for 1-TFA, and 385.1865 for 2-TFA with a tolerance of $\pm 5 \mathrm{ppm}$ for each sample. The retention time of signals obtained from reverse phase liquid chromatography (RPLC) was $5.15 \mathrm{~min}$ (DMCU), $3.97 \mathrm{~min}$ (1TFA), and $3.22 \mathrm{~min}$ (2-TFA) (Figure 3B). The limit of quantification was $0.16 \mathrm{ng}$ for DMCU $(\mathrm{S} / \mathrm{N}=375.81)$ and $1 \mathrm{ng}$ for 1-TFA $(\mathrm{S} / \mathrm{N}=231.24)$ or 2-TFA $(\mathrm{S} / \mathrm{N}=131.19)$. Compared to DMCU, the shorter retention time of 1-TFA or 2-TFA suggested that installation of the ethylene-carbonate-linked L-valine chain resulted in enhancement of hydrophilicity. Next, to determine the water solubility of DMCU, 1-TFA and 2-TFA, aqueous solutions of these compounds at different concentrations were prepared for the generation of corresponding calibration curves. 


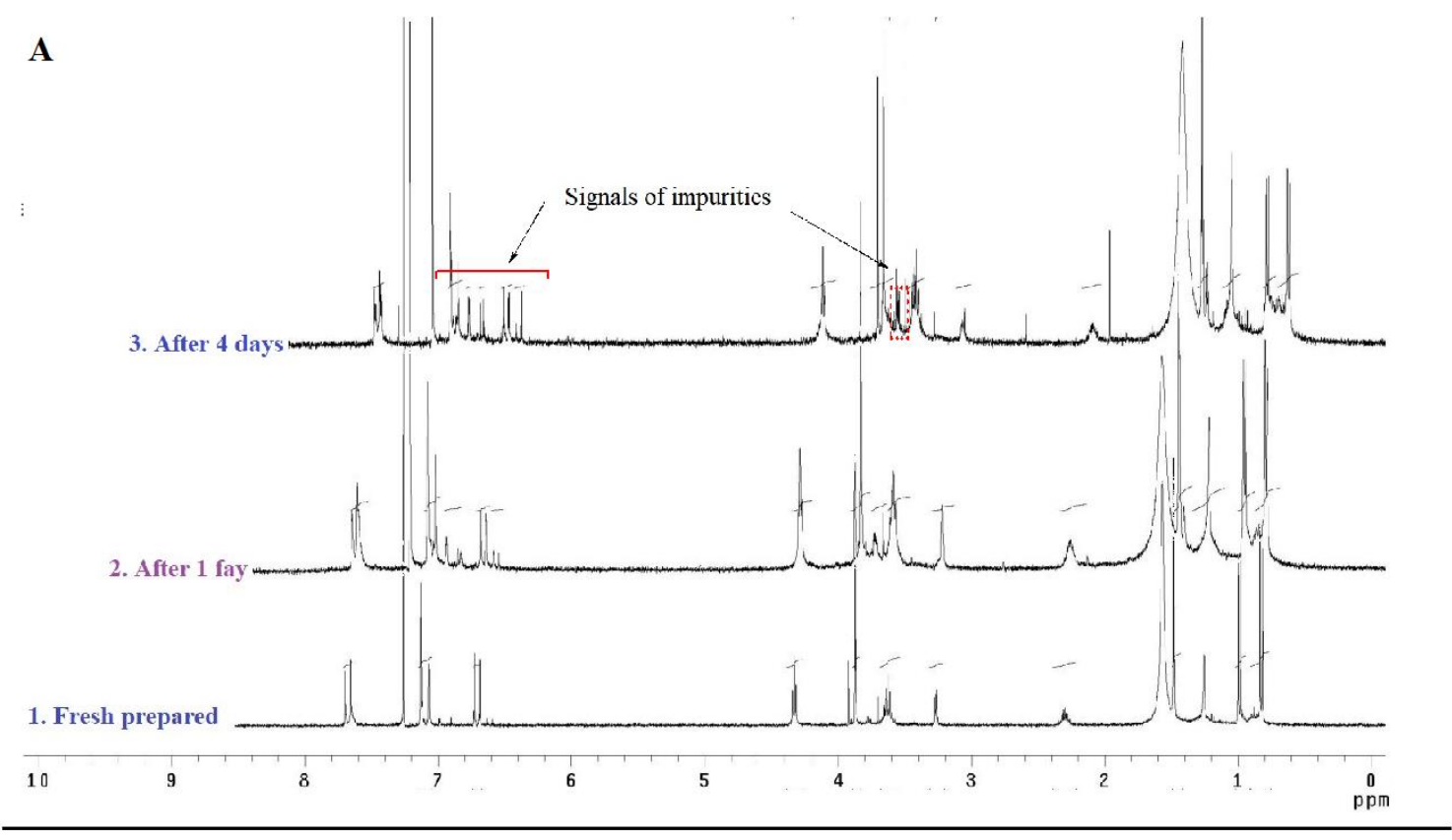

B (1) Fresh prepared, $95.74 \%$ HPLC purity

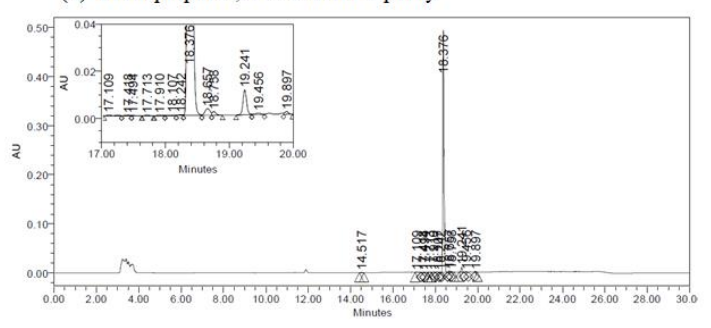

(2) Solid product was stored at room temperature for 6 days, $95.55 \%$

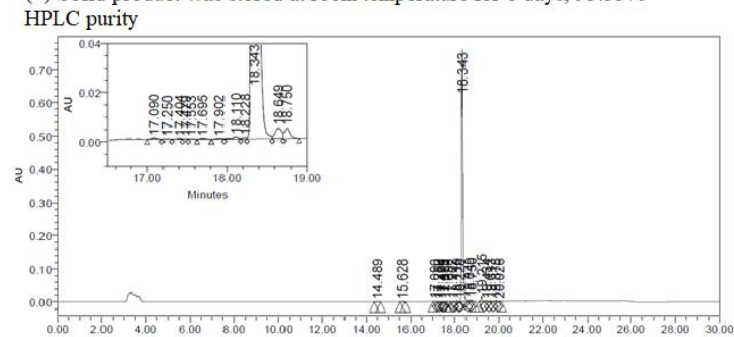

(3) Dissolved in DMSO and stored at room temperature for 6 days, $94.66 \%$ HPLC purity

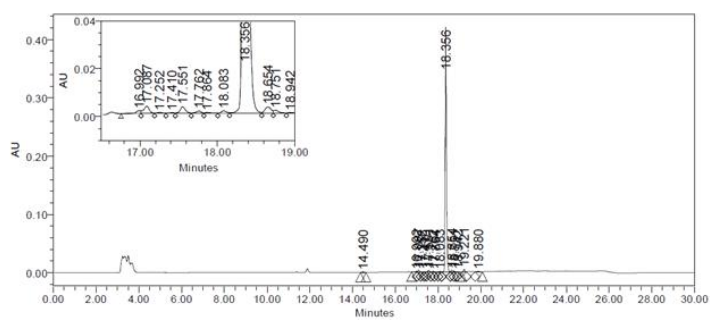

Figure 2. The stability assessments of $\mathbf{2}$ and 2-TFA. (A) A clear solution of $\mathbf{2}$ in $d$-chloroform was subjected to a purity assessment by ${ }^{1} \mathrm{H}$ NMR spectroscopy at various storage times (fresh prepared ( $\left.\leq 1 \mathrm{~h}\right) ; 1$ day; 4 days). (B) The HPLC purity of fresh prepared 2-TFA was $95.74 \%$. The fresh prepared 2-TFA in a solid state was stored at room temperature for another 6 days and then dissolved in water for HPLC analysis. The HPLC purity was decided as 95.55\%. The fresh prepared 2-TFA was dissolved in DMSO and the resulting solution was stored at room temperature for another 6 days. HPLC purity of 2-TFA in the DMSO solution was $94.66 \%$.

The quantitative analysis was performed using LC-MS and the results were shown in Figure 3C-E. Corresponding saturated water solutions were prepared and then diluted with ultrapure water for LC-MS analysis. Using interpolation of signal counted to the corresponding calibration curves, the solubility was decided as $249.7 \mathrm{mg} / \mathrm{mL}$ (1-TFA) and $375.8 \mathrm{mg} / \mathrm{mL}$ (2-TFA) at room temperature. For the analysis of DMCU water solubility, a clear solution of DMCU in $40 \% \mathrm{MeOH}$ and $60 \%$ water (with a concentration of $1000 \mathrm{ppm}$ ) was prepared and divided into four portions. Each part was diluted with an appropriate amount of ultrapure water, resulting in DMCU precipitates, and the precipitates were then removed by centrifugation to give four samples with theoretical concentrations of $0.8,4,20,100$ ppm, respectively. The calculated concentrations of these three samples 
were decided by comparing the LC-MS signals of corresponding samples to the calibration curves. (Figure 3F). The maximum concentration of DMCU in water was confirmed as 18 ppm at room temperature. These data indicated 13,700- and 20,800-fold increased solubility of 1-TFA and 2-TFA, respectively, compared to DMCU and supported our hypothesis that the chemical modification by the linkage of L-valine-TFA side chain on DMCU greatly improved the water solubility.

A
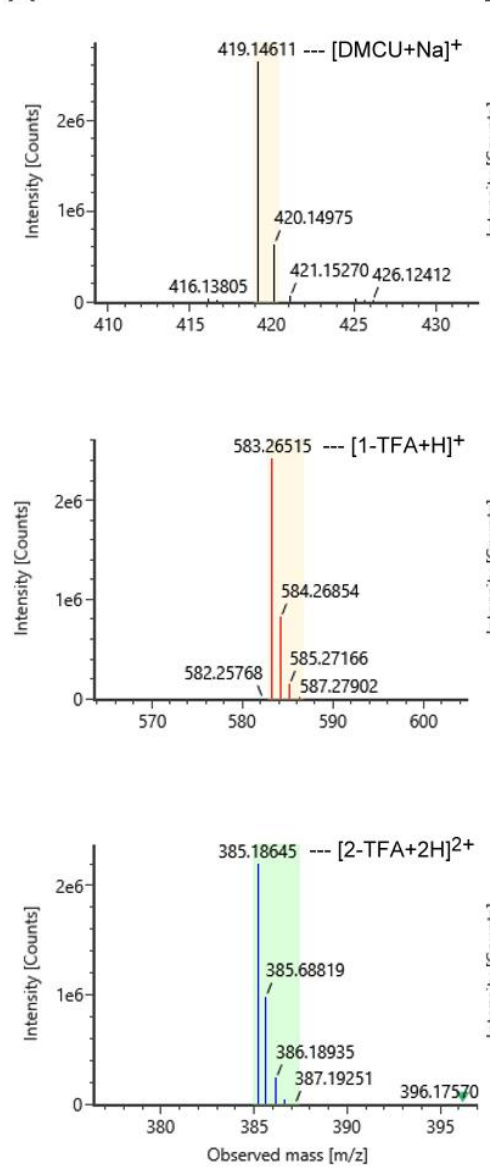

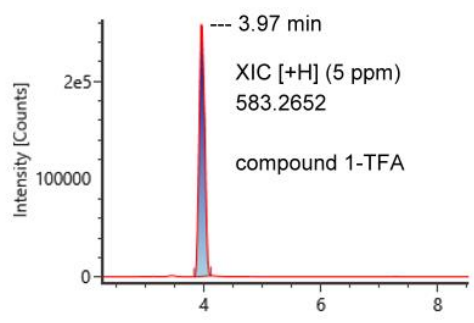

B
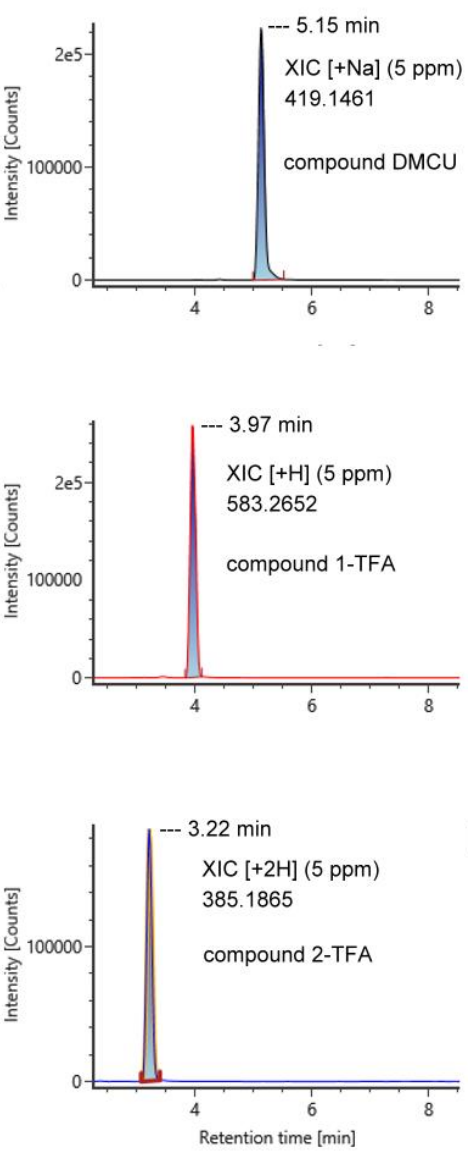

C ${ }_{5 . E+05}$
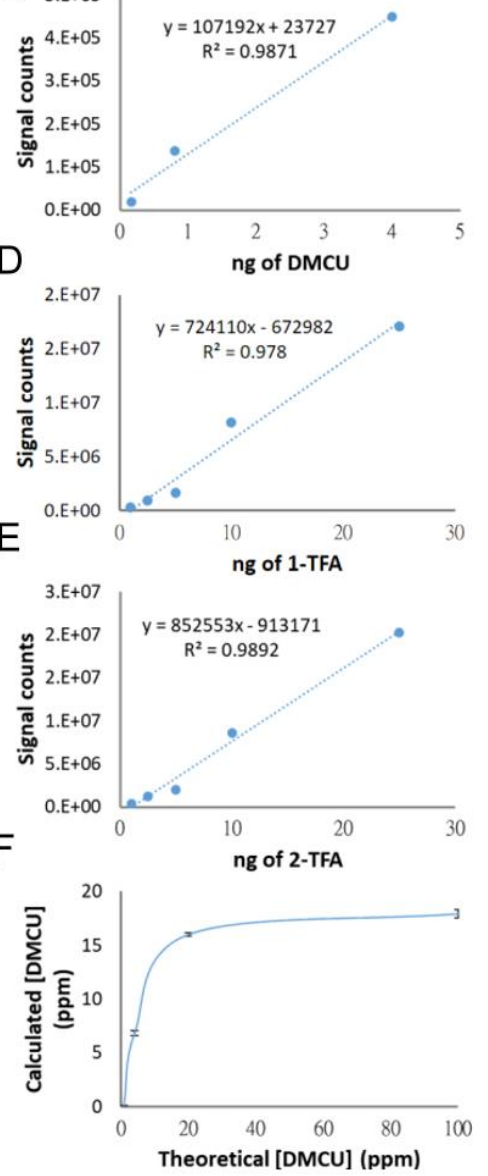

Figure 3. Quantification of water solubility of DMCU, 1-TFA, and 2-TFA. (A,B) Mass spectrum (A) and extracted ion chromatograms (XIC) (B) of DMCU, 1-TFA, and 2-TFA. (C-E) Calibration curves of DMCU (C), 1-TFA (D), and 2-TFA (E). (F) An investigation on the water solubility of DMCU. The solubility of all compounds was determined at room temperature.

\subsection{Anti-Proliferative Evaluation of 1-TFA, 2-TFA, and DMCU in LAT1-Expressing Lung Cancer Cells}

To evaluate anti-cancer activities of 1-TFA and 2-TFA, these two compounds and their reference compound DMCU were subjected to the anti-proliferative assay in human nonsmall-cell lung cancer cell (NSCLC) lines including NCI-H460, NCI-H358 and A549 cell lines (Table 1). As shown, the $\mathrm{IC}_{50}$ values of DMCU in these cell lines were $1.62-2.50 \mu \mathrm{M}$. Compound 2-TFA with two L-valine containing motifs showed the best anti-proliferative activity among three compounds in all of the NSCLC cell lines we tested. Moreover, compound 1-TFA with single ethylene-carbonate-linked L-valine chain showed stronger anticancer activity than its parent compound DMCU in NCI-H460 cells, but not in NCIH358 and A549 cells. Interestingly, previous studies showed that L-type amino acid transporters (LAT1) proteins is an amino acid carrier overexpressed in NCI-H460, NCIH358 and A549 NSCLC cell lines $[27,28]$. We hypothesized that the instillation of Lvaline containing side chains on DMCU, like 2-TFA, may not only greatly improve water solubility but also enhance cellular uptake and promote anti-cancer activity in NSCLC cells with LAT1 overexpression. 
Table 1. The anti-proliferative effects of DMCU, 1-TFA, and 2-TFA against NCI-H460, NCI-H358, and A549 lung cancer cell lines.

\begin{tabular}{cccc}
\hline \multirow{2}{*}{ Compound } & \multicolumn{3}{c}{ IC $_{\mathbf{5 0}}{ }^{\mathbf{a}, \mathbf{b}}(\boldsymbol{\mu M})$} \\
\cline { 2 - 4 } & NCI-H460 & NCI-H358 & A549 \\
\hline DMCU & $2.13 \pm 0.16$ & $1.62 \pm 0.12$ & $2.50 \pm 0.03$ \\
1-TFA & $1.95 \pm 0.16$ & $1.92 \pm 0.13$ & $3.17 \pm 0.14$ \\
2-TFA & $1.69 \pm 0.04$ & $1.26 \pm 0.06$ & $1.99 \pm 0.24$ \\
\hline
\end{tabular}

a. NCI-H460, NCI-H358 and A549 cancer cells were treated with different concentration of compounds for $72 \mathrm{~h}$.

b. Data are presented as mean $\pm \mathrm{SD}$.

\subsection{Evaluation of Intracellular Uptake and Bioconversion of DMCU, 1-TFA, and 2-TFA in NCI-H460 Cell Line}

To test our hypothesis, intracellular uptake of DMCU, 1-TFA, and 2-TFA were evaluated in NCI-H460 cells which cells were more sensitive to 1-TFA and 2-TFA than DMCU. The intracellular drug uptake was generally evaluated using a fluorescence microscope or flow cytometry $[29,30]$. However, the extremely similar chromophores among DMCU, 1-TFA, and 2-TFA caused failure in detection of individual signals by these two methodologies and therefore drew us to develop a versatile LC-MS based analysis for the cellular uptake evaluations. To estimate the cellular uptake, NCI-H460 cells were treated with each compound for the indicated time periods and the cell extracts were then subjected to LC-MS analysis to determine the intracellular levels of DMCU, 1-TFA, and TFA (Figure 4). In the treatment groups, the intracellular levels of each compound were detected by LC-MS where the amount of the compound was quantified by comparing the LC-MS signals of cellular extracts to the corresponding drug calibration curves. Accordingly, the maximal uptake of DMCU with a value of about $100 \mathrm{ng}$ was achieved at $1-2 \mathrm{~h}$ post-drug treatment (Figure 4A). In 1-TFA treated group, both 1-TFA and DMCU were detectable, suggesting that the bioconversion of 1-TFA to DMCU proceeded readily in the cells. The maximal uptake levels of 1-TFA and DMCU were detected by $60 \mathrm{ng}$ and $7 \mathrm{ng}$, respectively, at 60 min after treatment (Figure 4A,B). In 2-TFA treated group, the maximal cellular uptakes occurred during the time interval from 30 to $60 \mathrm{~min}$ after drug treatment and acquired $100 \mathrm{ng}$ of DMCU, $12 \mathrm{ng}$ of 1-TFA and $1.2 \mathrm{ng}$ of 2-TFA (Figure 4A-C). All these data implied that the bioconversion of 2-TFA happened to produce 1-TFA, which further converted to DMCU in the cells. The cellular uptake efficiency of H460 cells was then evaluated in terms of the total quantity of DMCU, 1-TFA, and 2-TFA. Total drug accumulation in 2-TFA-treated group was higher than that in DMCU-treated and 1-TFA-treated groups at 30 and $60 \mathrm{~min}$ after treatment (Figure 4D). These results indicated that 2-TFA were absorbed, accumulated in the NCI-H460 cancer cells and the intracellular 2-TFA were subsequently converted to DMCU and 1-TFA and therefore, treatment of 2-TFA exhibited stronger anti-cancer effects than DMCU and 1-TFA. 
A

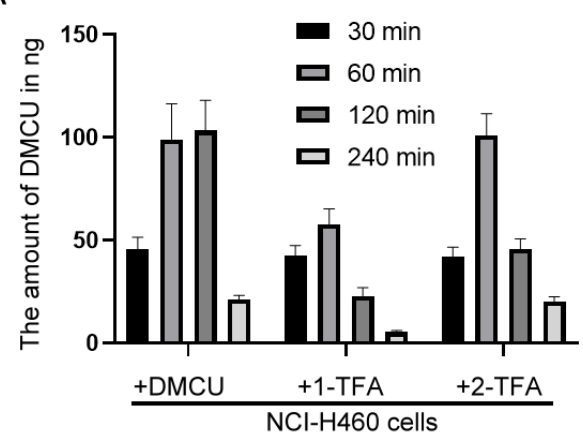

C

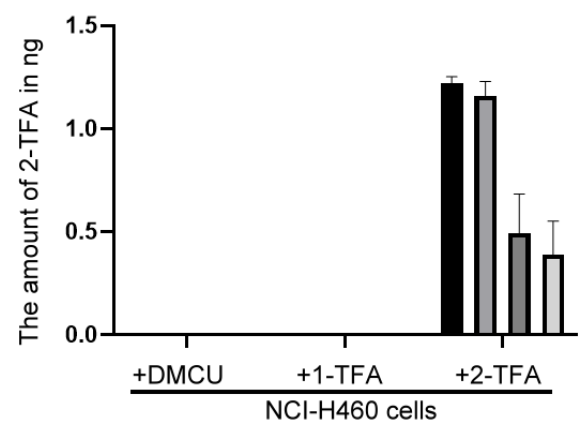

B

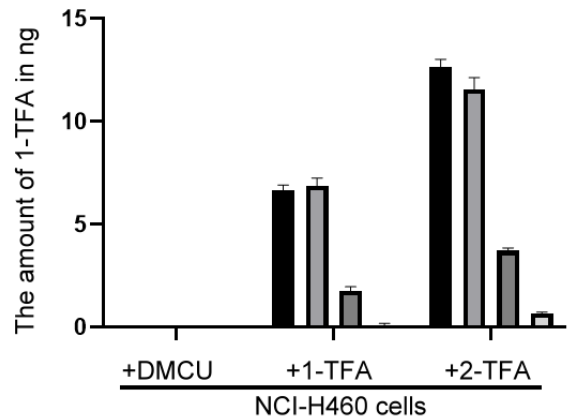

D

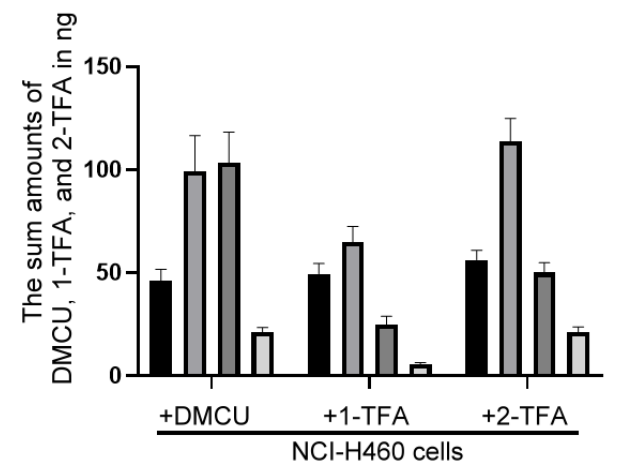

Figure 4. The intracellular levels of DMCU, 1-TFA and 2-TFA in the NCI-H460 cells. The cellular extracts were obtained from DMCU, 1-TFA, or 2-TFA treated cells at the indicated time intervals. The amount of drug uptake, (A) DMCU, (B) 1-TFA, (C) 2-TFA, or (D) sum amounts of DMCU, 1-TFA, and 2-TFA, was evaluated in the cellular extracts of approximately $1 \times 106$ cells by LC-MS analysis. Data are presented as mean and SD from three experiments.

\section{Materials and Methods}

\subsection{General Synthetic Methods}

The reactions were performed under an air atmosphere unless otherwise stated. All solvents and reagents were employed as received. Analytical thin-layer chromatography (TLC) was performed on $\mathrm{SiO}_{2} 60 \mathrm{~F}_{254}$ plates and flash column chromatography was carried out using $\mathrm{SiO}_{2} 60$ (particle size $0.040-0.055 \mathrm{~mm}, 230-400$ mesh), both of which are available from E. Merck (Darmstadt, Germany). Visualization was performed under UV irradiation at $254 \mathrm{~nm}$ followed by staining with aqueous potassium permanganate $\left[\mathrm{KMnO}_{4}(3 \mathrm{~g})\right.$ and $\mathrm{K}_{2} \mathrm{CO}_{3}(20 \mathrm{~g})$ in $300 \mathrm{~mL}$ of $\mathrm{H}_{2} \mathrm{O}$ containing $5 \mathrm{~mL}$ of an aqueous solution of $\mathrm{NaOH}$ $(5 \%, w / v)]$ and charring by heat gun. ${ }^{1} \mathrm{H}$ and ${ }^{13} \mathrm{C}$ NMR spectra were recorded on 500 or 400 FT NMR (Bruker, Billerica, MA, USA). Copies of ${ }^{1} \mathrm{H},{ }^{13} \mathrm{C}$ NMR and mass spectra of the synthetic products $(5,6,7,8,1$-TFA and 2-TFA) could be found in Supplementary Materials. Chloroform- $d$, methanol- $d$ and $d$-DMSO were used as solvents and TMS $(\delta=0.00 \mathrm{ppm})$ as an internal standard. Chemical shifts are reported as $\delta$ values in ppm as referenced to TMS. Multiplicities are recorded as s (singlet), $d$ (doublet), t (triplet), q (quartet), quint (quintet), sext (sextet), sept (septet), dd (doublet of doublets), dt (doublet of triplets), br (broad), $\mathrm{m}$ (multiplet). Coupling constants $(J)$ are expressed in Hz. LRMS values shown in the synthetic sections were measured by JMS-HX110 spectrometer (JEOL, Tokyo, Japan) and spectroscopic data were recorded as $m / z$ values.

\subsection{The Synthetic Procedures for 5, 6, 7, 8, 1-TFA and 2-TFA}

3.2.1. Tert-Butyl (S)-(1-((2-Hydroxyethyl)Amino)-3-Methyl-1-Oxobutan-2-yl)Carbamate (5)

To a stirred mixture of (2S)-2-(tert-butoxycarbonylamino)-3-methyl-butanoic acid (3) (4.000 g, $18.4 \mathrm{mmol}), 2$-aminoethanol $(4)(1.10 \mathrm{~mL}, 18.4 \mathrm{mmol})$ and $N, N, N^{\prime}, N^{\prime}$-tetramethyl-S-(1-oxido-2pyridyl)thiuronium hexafluorophosphate (HOTT) (13.663 g, $36.8 \mathrm{mmol})$ in $\mathrm{CH}_{3} \mathrm{CN}(180 \mathrm{~mL})$ 
was added triethylamine $(2.60 \mathrm{~mL}, 18.4 \mathrm{mmol})$ at room temperature. The resulting mixture was stirred at the same temperature for $23 \mathrm{~h}$ and then concentrated to dryness under vacuo. The crude product was purified by chromatography with ethyl acetate to get the tert-butyl (S)-(1-((2-hydroxyethyl)amino)-3-methyl-1-oxobutan-2-yl)carbamate (5) (3.930 g, 82\%) as a colorless oil.

${ }^{1} \mathrm{H}$ NMR (500 MHz, $\left.\mathrm{CDCl}_{3}\right): 5.54$ (br s, $\left.1 \mathrm{H}\right), 4.00$ (br s, $\left.1 \mathrm{H}\right), 3.87(\mathrm{t}, J=7.5 \mathrm{~Hz}, 1 \mathrm{H})$, 3.63-3.60 (m, 2H), 3.37-3.28 (m, 2H), 1.99-1.97 (m, 1H), $1.36(\mathrm{~s}, 9 \mathrm{H}), 0.90-0.86(\mathrm{~m}, 6 \mathrm{H}) ;{ }^{13} \mathrm{C}$ $\operatorname{NMR}\left(500 \mathrm{MHz}, \mathrm{CDCl}_{3}\right): 172.9,156.2,79.8,61.4,60.2,42.1,31.0,28.3,19.2,18.1$; LRMS $_{\text {[ES] }}{ }^{+}$ calculated for $\mathrm{C}_{12} \mathrm{H}_{24} \mathrm{NaN}_{2} \mathrm{O}_{4}: 283.16[\mathrm{M}+\mathrm{Na}]^{+}$; found: 283.25 ; HRMS [ESI] ${ }^{+}$calculated for $\mathrm{C}_{12} \mathrm{H}_{24} \mathrm{NaN}_{2} \mathrm{O}_{4}: 283.1634[\mathrm{M}+\mathrm{Na}]^{+}$; found: 283.1640 .

3.2.2. Tert-Butyl (S)-(3-Methyl-1-((2-(((4-Nitrophenoxy)Carbonyl)Oxy)Ethyl)Amino)-1Oxobutan-2-yl)Carbamate (6)

To a stirred solution of tert-butyl (S)-(1-((2-hydroxyethyl)amino)-3-methyl-1-oxobutan-2yl)carbamate (5) (4.815 g, $18.5 \mathrm{mmol})$ and 4-nitrophenyl chloroformate (4.095 g, $20.3 \mathrm{mmol})$ in $\mathrm{CH}_{2} \mathrm{Cl}_{2}(90 \mathrm{~mL})$ was added $\mathrm{N}$, N-diisopropylethylamine (DIPEA) $(4.756 \mathrm{~g}, 36.8 \mathrm{mmol})$ at room temperature. The resulting mixture was stirred at the same temperature for $4 \mathrm{~h}$ and then concentrated to dryness under vacuo. The crude residue was purified by chromatography (ethyl acetate/ $n$-hexane $=3: 2)$ to provide compound $6(6.805 \mathrm{~g}, 87 \%)$ as a white solid.

${ }^{1} \mathrm{H} \mathrm{NMR}\left(500 \mathrm{MHz} \mathrm{CDCl}_{3}\right): 8.27(\mathrm{~d}, J=9.0 \mathrm{~Hz}, 2 \mathrm{H}), 7.40(\mathrm{~d}, J=9.0 \mathrm{~Hz}, 2 \mathrm{H}), 6.54$ (br s, 1H), 5.06 (br s, 1H), $4.35(\mathrm{t}, J=5.5 \mathrm{~Hz}, 2 \mathrm{H}), 3.92-3.89(\mathrm{~m}, 1 \mathrm{H}), 3.69-3.62(\mathrm{~m}, 2 \mathrm{H}), 2.14-2.11$ $(\mathrm{m}, 1 \mathrm{H}), 1.43(\mathrm{~s}, 9 \mathrm{H}), 0.95(\mathrm{~d}, J=6.5 \mathrm{~Hz}, 3 \mathrm{H}), 0.93(\mathrm{~d}, J=6.5 \mathrm{~Hz}, 3 \mathrm{H}) ;{ }^{13} \mathrm{C} \mathrm{NMR}(500 \mathrm{MHz}$, $\left.\mathrm{CDCl}_{3}\right)$ : 172.2, 156.0, 155.4, 152.4, 145.5, 125.3, 121.7, 80.2, 67.8, 60.4, 42.1, 38.2, 30.6, 28.3, 19.2; LRMS [ES] ${ }^{+}$calculated for $\mathrm{C}_{19} \mathrm{H}_{27} \mathrm{~N}_{3} \mathrm{NaO}_{8}: 448.17$ [M + Na] ${ }^{+}$; found: 448.49; HRMS $[\mathrm{ESI}]^{+}$calculated for $\mathrm{C}_{19} \mathrm{H}_{27} \mathrm{~N}_{3} \mathrm{NaO}_{8}: 448.1696[\mathrm{M}+\mathrm{Na}]^{+}$; found: 448.1686.

\subsubsection{Compound 7}

To a mixture of DMCU (300 mg, $0.76 \mathrm{mmol})$ and cesium carbonate $(222 \mathrm{mg}, 0.68 \mathrm{mmol})$ in DMF (2 mL) was added tert-butyl (S)-(3-methyl-1-((2-((4-nitrophenoxy)carbonyl)oxy)ethyl)amino)1-oxobutan-2-yl)carbamate (6) $(290 \mathrm{mg}, 0.68 \mathrm{mmol})$ in DMF (3 mL). The reaction mixture was stirred at room temperature for $3.5 \mathrm{~h}$ and then quenched with quenched with saturated $\mathrm{NH}_{4} \mathrm{Cl}_{(\mathrm{aq})}$. The aqueous layer was separated and extracted with EtOAc $(3 \times 8 \mathrm{~mL})$. The combined organic extracts were washed with brine, dried over $\mathrm{MgSO}_{4}$, filtered and concentrated to give the crude product, which was purified on silica gel with ethyl acetate $/ n$-hexane (3:2) to afford $7(250 \mathrm{mg}, 0.37 \mathrm{mmol}, 48 \%)$ as a yellow solid. ${ }^{1} \mathrm{H} \mathrm{NMR}$ $\left(\mathrm{DMSO}_{6}, 500 \mathrm{MHz}\right) \delta 7.52(\mathrm{~d}, J=15.6 \mathrm{~Hz}, 2 \mathrm{H}), 7.44(\mathrm{~s}, 2 \mathrm{H}), 7.30(\mathrm{~d}, J=8.2 \mathrm{~Hz}, 2 \mathrm{H})$, 7.08-7.04 (m, 4H), 5.16 (br s, 6H), 4.19 (s, 4H), 3.78 (s, 6H), 3.61 (s, 8H), 1.17 (s, 6H); LRMS $[\mathrm{ESI}]^{+}$calculated for $\mathrm{C}_{33} \mathrm{H}_{40} \mathrm{O}_{14}: 661.25[\mathrm{M}+\mathrm{H}]^{+}$; found: 661.4 .

\subsubsection{Compound 8}

To a stirred mixture of DMCU ( $303 \mathrm{mg}, 0.76 \mathrm{mmol})$ and cesium carbonate ( $493 \mathrm{mg}, 1.5 \mathrm{mmol})$ in DMF (2 mL) was added tert-butyl (S)-(3-methyl-1-((2-((4-nitrophenoxy)carbonyl)oxy)ethyl)amino)-1oxobutan-2-yl)carbamate (6) $(888 \mathrm{mg}, 2.1 \mathrm{mmol})$ at room temperature. The resulting mixture was stirred at the same temperature for $6 \mathrm{~h}$ and then quenched with saturated $\mathrm{NH}_{4} \mathrm{Cl}_{(\mathrm{aq})}$ $(5 \mathrm{~mL})$. The aqueous layer was separated and extracted with EtOAc $(3 \times 8 \mathrm{~mL})$. The combined organic extracts were washed with brine, dried over $\mathrm{MgSO}_{4}$, filtered and concentrated to give the crude product, which was purified on silica gel with $\mathrm{EA} / n$-hexane (3:2) to afford 8 (500 $\mathrm{mg}, 68 \%)$ as a yellow solid.

${ }^{1} \mathrm{H}$ NMR $\left(400 \mathrm{MHz}, \mathrm{CDCl}_{3}\right): 7.68(\mathrm{~d}, J=15.6 \mathrm{~Hz}, 2 \mathrm{H}), 7.13-7.07(\mathrm{~m}, 6 \mathrm{H}), 6.70$ $(\mathrm{d}, J=15.6 \mathrm{~Hz}, 2 \mathrm{H}), 6.35($ br s, $1 \mathrm{H}), 5.02($ br s, $1 \mathrm{H}), 4.31(\mathrm{t}, J=5.2 \mathrm{~Hz}, 4 \mathrm{H}), 3.92-3.90$ $(\mathrm{m}, 2 \mathrm{H}), 3.87(\mathrm{~s}, 6 \mathrm{H}), 3.69-3.62(\mathrm{~m}, 4 \mathrm{H}), 2.17-2.12(\mathrm{~m}, 2 \mathrm{H}), 1.48(\mathrm{~s}, 6 \mathrm{H}), 1.43(\mathrm{~s}, 18 \mathrm{H}), 0.96(\mathrm{~d}$, $J=7.2 \mathrm{~Hz}, 6 \mathrm{H}), 0.91(\mathrm{~d}, J=6.4 \mathrm{~Hz}, 6 \mathrm{H})$; LRMS [ES] ${ }^{+}$calculated for $\mathrm{C}_{49} \mathrm{H}_{69} \mathrm{~N}_{4} \mathrm{O}_{16}: 969.47[\mathrm{M}$ $+\mathrm{H}]^{+}$; found: 970.06 . 


\subsubsection{Compound 1-TFA}

To a stirred solution of $7(260 \mathrm{mg}, 0.38 \mathrm{mmol})$ in $\mathrm{CH}_{2} \mathrm{Cl}_{2}(8 \mathrm{~mL})$ was added trifluoroacetic acid $(1.5 \mathrm{~mL}, 20.0 \mathrm{mmol})$ at $0{ }^{\circ} \mathrm{C}$. The reaction mixture was warmed to room temperature and stirred for $4 \mathrm{~h}$. The reaction medium was removed under vacuo to give the crude product, which was washed with $\mathrm{CH}_{2} \mathrm{Cl}_{2}(2 \mathrm{~mL} \times 3)$ and concentrated to dryness under vacuo to get the 1-TFA ( $264 \mathrm{mg}$, quantitative yield, $95 \%$ purity based on LC analysis) as a yellow solid.

${ }^{1} \mathrm{H}$ NMR $\left(400 \mathrm{MHz}, \mathrm{CD}_{3} \mathrm{OD}\right): 7.70-7.64(\mathrm{~m}, 2 \mathrm{H}), 7.33(\mathrm{~d}, J=1.6 \mathrm{~Hz}, 1 \mathrm{H}), 7.24-7.10(\mathrm{~m}$, $4 \mathrm{H}), 6.96(\mathrm{~d}, J=15.6 \mathrm{~Hz}, 1 \mathrm{H}), 6.84-6.79(\mathrm{~m}, 2 \mathrm{H}), 4.38-4.26(\mathrm{~m}, 2 \mathrm{H}), 3.87(\mathrm{~s}, 3 \mathrm{H}), 3.86(\mathrm{~s}, 3 \mathrm{H})$, $3.74-3.67(\mathrm{~m}, 1 \mathrm{H}), 3.63(\mathrm{~d}, J=5.6 \mathrm{~Hz}, 1 \mathrm{H}), 3.53-3.47(\mathrm{~m}, 1 \mathrm{H}), 2.22-2.13(\mathrm{~m}, 1 \mathrm{H}), 1.48(\mathrm{~s}, 6 \mathrm{H})$, 1.08-1.04 (m, 6 H). ${ }^{13} \mathrm{C}$ NMR (125 MHz, $d$-DMSO): 199.1, 198.8, 168.6, 158.8 (q, $\left.J=40.0 \mathrm{~Hz}\right)$, 152.7, 151.5, 150.1, 148.3, 144.4, 142.4, 141.4, 134.0, 126.1, 124.1, 123.2, 122.1, 119.0, 116.1, $113.1,112.2,67.5,59.9,58.1,56.6 ., 56.2,38.1,31.3,30.1,22.4,21.3,18.5,18.1,14.3$; LRMS [ES] ${ }^{+}$ calculated for $\mathrm{C}_{31} \mathrm{H}_{39} \mathrm{~N}_{2} \mathrm{O}_{9}: 583.26[\mathrm{M}+\mathrm{H}]^{+}$; found: 583.72; HRMS [ESI] ${ }^{+}$calculated for $\mathrm{C}_{31} \mathrm{H}_{39} \mathrm{~N}_{2} \mathrm{O}_{9}: 583.2650[\mathrm{M}+\mathrm{H}]^{+}$; found: 583.2651 .

\subsubsection{Compound 2-TFA}

To a solution of $8(316 \mathrm{mg}, 0.33 \mathrm{mmol})$ in $\mathrm{CH}_{2} \mathrm{Cl}_{2}(10 \mathrm{~mL})$ was added trifluoroacetic acid $(3 \mathrm{~mL}, 39.2 \mathrm{mmol})$ at $0{ }^{\circ} \mathrm{C}$. The reaction mixture was warmed to room temperature and stirred for $4 \mathrm{~h}$. The reaction medium was removed under vacuo to give the crude product, which was washed with $\mathrm{CH}_{2} \mathrm{Cl}_{2}(2 \mathrm{~mL} \times 3)$ and concentrated to dryness under vacuo to get the 2-TFA (323 $\mathrm{mg}$, quantitative yield, $95.8 \%$ purity based on LC analysis) as a yellow solid.

${ }^{1} \mathrm{H}$ NMR $\left(400 \mathrm{MHz}, \mathrm{CD}_{3} \mathrm{OD}\right): 7.69(\mathrm{~d}, J=15.6 \mathrm{~Hz}, 2 \mathrm{H}), 7.35(\mathrm{~d}, J=2.0 \mathrm{~Hz}, 2 \mathrm{H}), 7.26-$ $7.23(\mathrm{~m}, 2 \mathrm{H}), 7.14(\mathrm{~d}, J=8.0 \mathrm{~Hz}, 2 \mathrm{H}), 7.01(\mathrm{~d}, J=15.6 \mathrm{~Hz}, 2 \mathrm{H}), 4.38-4.26(\mathrm{~m}, 4 \mathrm{H}), 3.87(\mathrm{~s}, 6 \mathrm{H})$, $3.74-3.68(\mathrm{~m}, 2 \mathrm{H}), 3.64(\mathrm{~d}, J=5.2 \mathrm{~Hz}, 2 \mathrm{H}), 3.53-3.47(\mathrm{~m}, 2 \mathrm{H}), 2.22-2.14(\mathrm{~m}, 2 \mathrm{H}), 1.50(\mathrm{~s}, 6 \mathrm{H})$, 1.08-1.05 (m, 12H); ${ }^{13} \mathrm{C}$ NMR (125 MHz, $d$-DMSO): 199.2, 168.6, 158.8 (q, $\left.J=41.2 \mathrm{~Hz}\right), 152.7$, 151.5, 142.6, 141.4, 134.0, 123.2, 123.0, 122.6, 113.1, 67.5, 60.0, 58.1, 56.5, 38.1, 30.1, 21.1, 18.5, 18.1; LRMS [ES] ${ }^{+}$calculated for $\mathrm{C}_{39} \mathrm{H}_{54} \mathrm{~N}_{4} \mathrm{O}_{12}: 385.18[\mathrm{M}+2 \mathrm{H}]^{2+}$; found: 385.94 ; HRMS $[\mathrm{ESI}]^{+}$calculated for $\mathrm{C}_{39} \mathrm{H}_{54} \mathrm{~N}_{4} \mathrm{O}_{12}: 385.1863[\mathrm{M}+2 \mathrm{H}]^{2+}$; found: 385.1864

\subsection{Biological Assays}

\subsubsection{Cell Culture}

Human NSCLC cell lines (NCI-H460, NCI-H358 and A549) were obtained from ATCC. All cell lines were grown in RPMI medium supplemented with $10 \%$ fetal bovine serum (FBS) and antibiotics and incubated at $37^{\circ} \mathrm{C}$ in a humidified atmosphere with $5 \% \mathrm{CO}_{2}$.

\subsubsection{In Vitro Antiproliferative Assay}

Antiproliferative activities to various compounds was assessed using MTT assay [31]. In brief, 2000-5000 cells were seeded in each well of 96-well plates and incubated at $37^{\circ} \mathrm{C}$ overnight before drug treatment. After a three-day drug treatment, MTT solution was added to each well and the plates were further incubated at $37^{\circ} \mathrm{C}$ for $6 \mathrm{~h}$. Measurement of cell viability was assessed by absorbance at $570 \mathrm{~nm}$. The $\mathrm{IC}_{50}$ values for each drug were determined using CompuSyn software based on the median-effect principle and plot.

\subsection{Preparation of Standard Solution of DMCU, 1-TFA and 2-TFA}

The stock solutions of 1-TFA and 2-TFA were prepared by dissolving $20 \mathrm{mg}$ of 1-TFA and 2-TFA, respectively, in $1 \mathrm{~mL}$ of $1 \%$ formic $\operatorname{acid}_{(\mathrm{aq})}$. The standard solution of 1-TFA or 2-TFA of $0.5,1.25,2.5,5$ and $12.5 \mu \mathrm{g} / \mathrm{mL}$ was prepared by diluting the aforementioned stock solution with an adequate amount of $40 \%$ methanol in ultrapure water. The stock solution of DMCU was prepared by dissolving $10 \mathrm{mg}$ of DMCU in $1 \mathrm{~mL}$ of methanol. The DMCU stock solution was diluted with $40 \%$ methanol in ultrapure water to afford three standard solutions with concentrations of $0.08,0.4$, and $2 \mu \mathrm{g} / \mathrm{mL}$. 


\subsection{Preparation of Aqueous Solution of 1-TFA and 2-TFA for Solubility Analysis}

The saturated aqueous solutions of compound 1-TFA and 2-TFA were prepared by a three-steps sequence including supersaturated solution preparation (addition of $20 \mathrm{mg}$ compounds into $50 \mu \mathrm{L}$ ultrapure water), centrifugation (10 min at $14,000 \times g)$, and collection of the resulting supernatants to afford the desired solutions. The saturated aqueous solutions were then diluted by ultrapure water as the ratio of 1 to 100,000 for LC-MS analysis.

\subsection{Analysis Method of LC-MS}

The LC-MS system consisted of an ultraperformance liquid chromatography (UPLC) system (ACQUITY UPLC I-Class, Waters, Milford, MA, USA and an ESI/APCI source of $4 \mathrm{kDa}$ quadrupole time-of-flight mass spectrometer (Waters VION, Waters, Milford, MA, USA). A BEH C18 column $(2.1 \times 100 \mathrm{~mm}$, Walters, Milford, MA, USA) was equipped to perform chromatographic separation. The flow rate of $0.2 \mathrm{~mL} / \mathrm{min}$ with a column temperature of $35^{\circ} \mathrm{C}$ was set for each sample injection. The elution started with $60 \%$ mobile phase A (ultrapure water $+0.1 \%$ formic acid) and $40 \%$ mobile phase B (100\% methanol $+0.1 \%$ formic acid), then held at $40 \%$ B for $0.5 \mathrm{~min}$, raised to $95 \% \mathrm{~B}$ in $5.5 \mathrm{~min}$, held at $95 \%$ B for $1 \mathrm{~min}$, and then lowered to $40 \% \mathrm{~B}$ in $1 \mathrm{~min}$. The column was equilibrated by pumping $40 \%$ B for $4 \mathrm{~min}$. The LC-MS data were acquired using ESI+ mode under the following conditions: capillary voltage of $2.5 \mathrm{kV}$, source temperature of $100{ }^{\circ} \mathrm{C}$, desolation temperature of $250{ }^{\circ} \mathrm{C}$, cone gas maintained at $10 \mathrm{~L} / \mathrm{h}$, desolation gas maintained at $600 \mathrm{~L} / \mathrm{h}$, and acquisition by MS $\mathrm{S}^{\mathrm{E}}$ mode with a range of $100-1000 \mathrm{~m} / \mathrm{z}$ and a 0.5 -s scan time. The data were acquired and processed using UNIFI software (Waters, Milford, MA, USA).

\subsection{Cell Extracts for LC-MS Analysis}

NCI-H460 cells, inoculated in the 6-well plates, were maintained at $37^{\circ} \mathrm{C}$ for $24 \mathrm{~h}$ and treated with $10 \mu \mathrm{M}$ of DMCU, 1-TFA or 2-TFA. The cells were cultured at $37^{\circ} \mathrm{C}$ for $0.5,1$, 2 and $4 \mathrm{~h}$, respectively. For each well, the used medium was removed and the residual cells were washed with $1 \mathrm{~mL}$ of fresh PBS three times. After completely removing the residual solution, $100 \mu \mathrm{L}$ of ultrapure water was added and vigorous pipetting was performed to disrupt the cells. After centrifuging at $14,000 \times g$ for $10 \mathrm{~min}, 40$ all of supernatant from cell homogenate was collected and then mixed with $160 \mu \mathrm{L}$ of methanol. The resulting mixture was stored at $-80^{\circ} \mathrm{C}$ and used as an aliquot of cell extract. For LC-MS analysis, the frozen cell extract was warmed to room temperature and centrifuged at $14,000 \times g$ for $10 \mathrm{~min}$ to provide the supernatant, which was used directly for sample injection.

\section{Conclusions}

Here, we have developed two DMCU derivatives, 1-TFA and 2-TFA, as effective anticancer agents against NSCLCs with LAT-1 expression. The present study provides a direction for future structural modification of curcuminoid-like phenolic compounds. Additional works on the changes of L-valine into other BCAAs have been scheduled for enhancement of cellular uptake in lung cancer cells. For the evaluation of drug uptake, an alternative estimation method based on the LC-MS was established and revealed that modification of DMCU into 2-TFA facilitated the cell uptake. Such outcomes are in line with the superior anticancer activity of 2-TFA. However, the factors that caused the disparities between the antiproliferative effects and cellular uptake abilities in the DMCU and 1-TFA treated groups are still unclear. Further evaluations and mechanism studies will be performed in the future.

Supplementary Materials: The following are available online. Copies of 1H, 13C NMR and mass spectra of the synthetic products $(5,6,7,8,1$-TFA and 2-TFA). 
Author Contributions: D.-Y.L. performed the LC-MS analysis, designed the figures and drafted the manuscript. H.-Y.L. carried out the in vitro antiproliferative assay. M.R. synthesized the targeted compounds. S.-C.K. provided scientific input and wrote the manuscript. M.-T.H. designed and synthesized targeted compounds, and wrote the manuscript. Conceived the in vitro assay, interpret the results, and wrote the manuscript. M.-T.H. and P.-C.L. are the responsible researchers, who provided the final version of the manuscript. All authors have read and agreed to the published version of the manuscript.

Funding: This research was funded by the Ministry of Science and Technology, Taiwan [MOST 1082320-B-039-036], Chinese Medicine Research Center, China Medical University from The Featured Areas Research Center Program within the framework of the Higher Education Sprout Project by the Ministry of Education (MOE) in Taiwan (CMRC-CHM-5) and China Medical University [CMU109-S35 \& YingTsai Young Scholar Award (CMU108-YTY-03)]. And the APC was funded by Ministry of Science and Technology, Taiwan.

Institutional Review Board Statement: Not applicable.

Informed Consent Statement: Not applicable.

Data Availability Statement: The data present in this study are available on the request from the corresponding authors.

Acknowledgments: We are grateful to Ministry of Science and Technology, Ministry of Education, China Medical University. Taiwan for financial support.

Conflicts of Interest: The authors declare no conflict of interest.

Sample Availability: Not applicable.

\section{References}

1. Kikuchi, H.; Yuan, B.; Hu, X.; Okazaki, M. Chemopreventive and anticancer activity of flavonoids and its possibility for clinical use by combining with conventional chemotherapeutic agents. Am. J. Cancer Res. 2019, 8, 1517-1535.

2. Singh, V.K.; Arora, D.; Ansari, M.I.; Sharma, P.K. Phytochemicals based chemopreventive and chemotherapeutic strategies and modern technologies to overcome limitations for better clinical applications. Phytother. Res. 2019, 33, 3064-3089. [CrossRef]

3. Luna-Guevara, M.L.; Luna-Guevara, J.J.; Hernandez-Carranza, P.; Ruiz-Espinosa, H.; Ochoa-Velasco, C.E. Phenolic compounds: A good choice against chronic degenerative diseases. Stud. Nat. Prod. Chem. 2018, 59, 79-108.

4. Fernandez-Panchon, M.S.; Villano, D.; Troncoso, A.M.; Garcia-Parrilla, M.C. Antioxidant activity of phenolic compounds: From in vitro results to in vivo evidence. Crit. Rev. Food Sci. Nutr. 2008, 48, 649-671. [CrossRef]

5. Ashrap, P.; Zheng, G.; Wan, Y.; Li, T.; Hu, W.; Li, W.; Zhang, H.; Zhang, Z.; Hu, J. Discovery of a widespread metabolic pathway within and among phenolic xenobiotics. Proc. Natl. Acad. Sci. USA 2017, 23, 6062-6067. [CrossRef]

6. Liu, B.M.; Bai, C.L.; Zhang, J.; Liu, Y.; Dong, B.Y.; Zhang, Y.T.; Liu, D. In Vitro study on the interaction of 4,4-dimethylcurcumin with calf thymus DNA. J. Lumin. 2015, 166, 48-53. [CrossRef]

7. Oliveira, A.S.; Sousa, E.; Vasconcelos, M.H.; Pinto, M. Curcumin: A natural lead for potential new drug candidates. Curr. Med. Chem. 2015, 22, 4196-4232. [CrossRef]

8. Liu, B.; Xia, M.; Ji, X.; Xu, L.; Dong, J. Synthesis and antiproliferative effect of novel curcumin analogues. Chem. Pharm. Bull. 2013, 61, 757-763. [CrossRef]

9. Tu, Z.S.; Wang, Q.; Sun, D.D.; Dai, F.; Zhou, B. Design, synthesis, and evaluation of curcumin derivatives as Nrf2 activators and cytoprotectors against oxidative death. Eur. J. Med. Chem. 2017, 134, 72-85. [CrossRef]

10. Yang, Y.; Aloysius, H.; Inoyama, D.; Chen, Y.; Hu, L. Enzyme-mediated hydrolytic activation of prodrugs. Acta Pharm. Sin. B 2011, 1, 143-159. [CrossRef]

11. Hsieh, M.T.; Chang, L.C.; Hung, H.Y.; Lin, H.Y.; Shih, M.H.; Tsai, C.H.; Kuo, S.C.; Lee, K.H. New bis(hydroxymethyl) alkanoate curcuminoid derivatives exhibit activity against triple-negative breast cancer in vitro and in vivo. Eur. J. Med. Chem. 2017, 131, 141-151. [CrossRef]

12. Chang, L.C.; Hsieh, M.T.; Yang, J.S.; Lu, C.C.; Tsai, F.J.; Tsao, J.W.; Chiu, Y.J.; Kuo, S.C.; Lee, K.H. Effect of bis(hydroxymethyl) alkanoate curcuminoid derivative MTH-3 on cell cycle arrest, apoptotic and autophagic pathway in triple-negative breast adenocarcinoma MDA-MB-231 cells: An in vitro study. Int. J. Oncol. 2018, 52, 67-76. [CrossRef]

13. Lee, D.Y.; Hou, Y.C.; Yang, J.S.; Lin, H.Y.; Chang, T.Y.; Lee, K.H.; Kuo, S.C.; Hsieh, M.T. Synthesis, anticancer activity, and preliminary pharmacokinetic evaluation of 4,4-disubstituted curcuminoid 2,2-bis(Hydroxymethyl)propionate derivatives. Molecules 2020, 25, 479. [CrossRef]

14. Barthelemy, C.; André, B. Ubiquitylation and endocytosis of the human LAT1/SLC7A5 amino acid transporter. Sci. Rep. 2019, 9, 16760. [CrossRef] 
15. Häfliger, P.; Charles, R.P. The L-Type Amino Acid Transporter LAT1-An Emerging Target in Cancer. Int. J. Mol. Sci. $2019,20,2428$. [CrossRef]

16. Lieu, E.L.; Nguyen, T.; Rhyne, S.; Kim, J. Amino acids in cancer. Exp. Mol. Med. 2020, 52, 15-30. [CrossRef]

17. Hodson, N.; Brown, T.; Joanisse, S.; Aguirre, N.; West, D.W.D.; Moore, D.R.; Baar, K.; Breen, L.; Philp, A. Characterisation of L-type amino acid transporter 1 (LAT1) expression in human skeletal muscle by immunofluorescent microscopy. Nutrients 2017, 10, 23. [CrossRef]

18. Takeuchi, K.; Ogata, S.; Nakanishi, K.; Ozeki, Y.; Hiroi, S.; Tominaga, S.; Aida, S.; Matsuo, H.; Sakata, T.; Kawai, T. LAT1 expression in non-small-cell lung carcinomas: Analyses by semiquantitative reverse transcription-PCR (237 cases) and immunohistochemistry (295 cases). Lung Cancer 2010, 68, 58-65. [CrossRef]

19. Kaira, K.; Oriuchi, N.; Takahashi, T.; Nakagawa, K.; Ohde, Y.; Okumura, T.; Murakami, H.; Shukuya, T.; Kenmotsu, H.; Naito, T.; et al. LAT1 expression is closely associated with hypoxic markers and mTOR in resected non-small cell lung cancer. Am. J. Transl. Res. 2011, 3, 468-478.

20. Lopes, C.; Pereira, C.; Medeiros, R. ASCT2 and LAT1 Contribution to the hallmarks of cancer: From a molecular perspective to clinical translation. Cancers 2021, 13, 203. [CrossRef]

21. Vale, N.; Ferreira, A.; Matos, J.; Fresco, P.; Gouveia, M.J. Amino acids in the development of prodrugs. Molecules 2018, 23, 2318. [CrossRef]

22. Puris, E.; Gynther, M.; Auriola, S.; Huttunen, K.M. L-Type amino acid transporter 1 as a target for drug delivery. Pharm. Res. 2020, 37, 88. [CrossRef] [PubMed]

23. Huttunen, J.; Peltokangas, S.; Gynther, M.; Natunen, T.; Hiltunen, M.; Auriola, S.; Ruponen, M.; Vellonen, K.S.; Huttunen, K.M. L-type amino acid transporter 1 (LAT1/Lat1)-utilizing prodrugs can improve the delivery of drugs into neurons, astrocytes and microglia. Sci. Rep. 2019, 9, 12860. [CrossRef] [PubMed]

24. Tranoy-Opalinski, I.; Fernandes, A.; Thomas, M.; Gesson, J.P.; Papot, S. Design of self-immolative linkers for tumour-activated prodrug therapy. Anti-Cancer Agents Med. Chem. 2008, 8, 618-637. [CrossRef]

25. Selwan, E.M.; Edinger, A.L. Branched chain amino acid metabolism and cancer: The importance of keeping things in context. Transl. Cancer Res. 2017, 6, S578-S584. [CrossRef] [PubMed]

26. Basile, V.; Ferrari, E.; Lazzari, S.; Belluti, S.; Pignedoli, F.; Imbriano, C. Curcumin derivatives: Molecular basis of their anti-cancer activity. Biochem. Pharmacol. 2009, 78, 1305-1315. [CrossRef] [PubMed]

27. Imai, H.; Kaira, K.; Oriuchi, N.; Shimizu, K.; Tominaga, H.; Yanagitani, N.; Sunaga, N.; Ishizuka, T.; Nagamori, S.; Promchan, K.; et al. Inhibition of L-type amino acid transporter 1 has antitumor activity in non-small cell lung cancer. Anticancer Res. 2010, 30 , $4819-4828$.

28. Gwinn, D.M.; Lee, A.G.; Briones-Martin-Del-Campo, M.; Conn, C.S.; Simpson, D.R.; Scott, A.I.; Le, A.; Cowan, T.M.; Ruggero, D.; Sweet-Cordero, E.A. Oncogenic KRAS regulates amino acid homeostasis and asparagine biosynthesis via ATF4 and alters sensitivity to L-asparaginase. Cancer Cell 2018, 33, 91-107. [CrossRef]

29. Fernando, L.P.; Kandel, P.K.; Yu, J.; McNeill, J.; Ackroyd, P.C.; Christensen, K.A. Mechanism of cellular uptake of highly fluorescent conjugated polymer nanoparticles. Biomacromolecules 2010, 11, 2675-2682. [CrossRef]

30. Semmling, M.; Kreft, O.; Muñoz Javier, A.; Sukhorukov, G.B.; Käs, J.; Parak, W.J. A novel flow-cytometry-based assay for cellular uptake studies of polyelectrolyte microcapsules. Small 2008, 4, 1763-1768. [CrossRef]

31. Stockert, J.C.; Blázquez-Castro, A.; Cañete, M.; Horobin, R.W.; Villanueva, A. MTT assay for cell viability: Intracellular localization of the formazan product is in lipid droplets. Acta Histochem. 2012, 114, 785-796. [CrossRef] [PubMed] 